\title{
Good management practices course and social technologies for aquaculture farmers in Marajó, Pará, Brazil
}

The objective of this study was capacitate aquaculture farmers and develop social technologies for the culture of tambaqui (Colossoma macropomum) in the archipelago of Marajó (Pará - Brazil). The study was carried out in the municipality of Curralinho by the Federal Institute of Education, Science and Technology of Pará (IFPA) Campus Breves, in March 2020. Two structured questionnaires were applied to 13 course participants who participated in the training. The first was before the course, about fish farming and the adoption of Good Management Practices (BPM) adopted by aquaculture farmers in the Marajó region. The second composed of closed questions to evaluate the training course, whose themes were: 1) water quality, 2) indicated species, 3) fish transport management, 4) fish quarantine and stock, 5) fish biometrics, 6) liming and fertilizing ponds, 7) management of fish nutrition and health, and 8) fish harvesting and slaughter, were approached in the course. At the end of the lectures/training, a workshop for the production of social technologies was conducted, among students, teachers and aquaculture farmers. Previous knowledge about fish farming and the adoption of BPM were essential for the effectuation of the course. Issues about water quality, biometrics and fish nutrition and health were the ones that called the most attention from aquaculture farmers. Secchi's disk, ichthyometer, hand net and nettank were the social technologies built. Post-course evaluation was essential to understand the impact of the socialization of knowledge provided to the community. In conclusion, the project reinforced teaching, research and extension actions, involving the community in favor of strengthening aquaculture in the Marajó island, Pará, Brazil.

\section{Curso de boas práticas de gestão e tecnologias sociais para aquicultores de Marajó, Pará, Brasil}

\begin{abstract}
O objetivo deste estudo foi capacitar aquicultores e desenvolver tecnologias sociais para a cultura do tambaqui (Colossoma macropomum) no arquipélago do Marajó (Pará - Brasil). O estudo foi realizado no município de Curralinho pelo Instituto Federal de Educação, Ciência e Tecnologia do Pará (IFPA) Campus Breves, em março de 2020. Foram aplicados dois questionários estruturados para 13 cursistas que participaram da capacitação. $O$ primeiro, foi antes do curso, sobre a piscicultura e adoção de Boas Práticas de Manejo (BPM) adotados pelos aquicultores na região do Marajó. O segundo, composto por perguntas fechadas para avaliar o curso de capacitação, cujo os temas foram: 1) qualidade da água, 2) espécies indicadas, 3) manejo de transporte de peixes, 4) quarentena e povoamento dos peixes, 5) manejo de biometria de peixe, 6) calagem e adubação de viveiros, 7) manejo de nutrição, alimentação e sanidade de peixes, e 8) despesca e abate de peixe, foram abordados no curso. Ao final das palestras/ou capacitação, foi conduzida uma oficina para produção de tecnologias sociais, entre estudantes, professores e aquicultores. $O$ projeto capacitou homens e mulheres de diversas comunidades rurais e da cidade de Curralinho. $O$ conhecimento prévio sobre a piscicultura e adoção de BPM, foram essenciais para a efetivação do curso. Assuntos sobre a qualidade da água, a biometria e a nutrição e sanidade de peixes, foram os que chamaram mais atenção dos aquicultores. O disco de Secchi, ictiômetro, puçá e tanque-rede, foram as tecnologias sociais construídas. A avaliação pós curso foi essencial para entender o impacto da socialização do conhecimento prestado à comunidade. Em conclusão, o projeto reforçou as ações de ensino, pesquisa e extensão, envolvendo a comunidade em prol do fortalecimento da aquicultura no Marajó, Pará, Brasil.
\end{abstract}

Palavras-chave: Tambaqui; Fortalecimento; Extensão; Amazônia paraense.

Topic: Extensão e Desenvolvimento Rural

Reviewed anonymously in the process of blind peer.
Received: $\mathbf{1 1 / 0 5 / 2 0 2 0}$

Approved: 04/06/2020
Fabricio Nilo Lima da Silva (i) Instituto Federal do Pará, Brasil http://lattes.cnpq.br/1728474813538054 http.//orcid org/0000-0002-6402-0540 fabricio nilo@hotmail.com

Raoani Cruz Mendonça (iD) Instituto Federal do Pará, Brasi http://lattes.cnpq.br/4003101012437664 http://orcid.org/0000-0001-6629-680X http://orcid.org/000

Manoel Luciano Aviz de Quadros (iD) Instituto Federal do Pará, Brasil http://lattes.cnpq.br/1220165281362281 http://orcid.org/0000-0002-8258-7620 manoel.quadros@ifpa.edu.br
Luã Caldas de Oliveira (1D) Instituto Federal do Pará, Brasil http://lattes.cnpq.br/5265483993666093 http://orcid.org/0000-0001-7246-8559 lua.oliveira@ifpa.edu.br

Osnan Lennon Lameira Silva (iD Universidade Federal do Pará, Brasil http://lattes.cnpq.br/5468558861341077 http://orcid.org/0000-0001-6516-5007 osnanlennon@hotmail.com

Antônia Rafaela Gonçalves Macedo Universidade Federal do Pará, Brasil http://lattes.cnpq.br/2108343644028043 http://orcid.org/0000-0002-3667-2234 argmaquicultura@hotmail.com

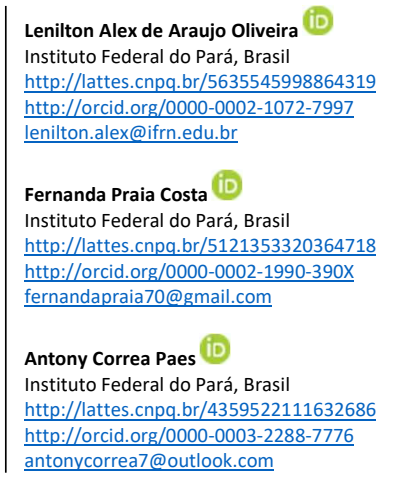

Aracy Sá Pereira (id Instituto Federal do Pará, Brasi http://lattes.cnpq.br/9820029830189678 http://orcid.org/0000-0003-1609-4024 aracysapereira95@gmail.com

Referencing this:

SILVA, F. N. L.; MENDONÇA, R. C.; QUADROS, M. L. A.; OLIVEIRA, L. C.; SILVA, O. L. L.; MACEDO, A. R. G.; ARAUJO, L. A.; COSTA, F. P.; PAES, A. C.; PEREIRA, A. S. Good management practices course and social technologies for aquaculture farmers in Marajó, Pará, Brazil. Revista Ibero Americana de Ciências Ambientais, v.11, n.4, p.49-58, 2020. DOI: http://doi.org/10.6008/CBPC2179-6858.2020.004.0004 


\section{INTRODUCTION}

The Brazil has enormous potential for the development of aquaculture (SILVA et al., 2018; MEDEIROS et al., 2017). The water resources of the Amazon, the favorable climate and the geographical condition, are essential factors for its growth (DANTAS et al., 2019; FERREIRA et al., 2020). Fish farming in the State of Pará is growing and is an activity developed by small, medium and large aquaculture farmers. An activity also performed by family farming, extractivists and riverside dwellers (AIZAWA et al., 2014; ZACARDI et al., 2017).

Given this perspective, the Federal Institute of Education, Science and Technology of Pará (IFPA) Campus Breves has been contributing to the strengthening of the aquaculture sector, generating qualified labor for the Marajó archipelago, Pará, Brazil. In 2019, the institution inserted the first class of the Technical course in Aquaculture, with a hub in the municipality of Curralinho in partnership with the City Hall and the Z-37 fishing colony. These enable students to work in the Marajó region, in which aquaculture is economically important.

Aquaculturists in Curralinho, for example, cultivate tambaqui (Colossoma macropomum Cuvier, 1818), for subsistence and the surplus is commercialized. However, the culture of the species is practiced in small structures, with low technological development and uses empirical knowledge. Local fish farming contributes to rural development, enables economic returns to producers, contributes to job creation and optimizes the natural resources on the properties. On the contrary, many producers have been presenting problems when developing the activity, due to the lack of Good Management Practices (BPM) in fish farming. A compatible and realistic alternative consists of providing training courses and developing social technologies that are adaptable to the problems experienced by the producer (FAO, 2006; KLEIN et al., 2009; SANTOS FILHO et al., 2016; AKTER et al., 2019; SAMAH, 2020).

Thus, the transfer of knowledge through training, aims at the growth of aquaculture, in order to generate income (KATO et al., 2017; FEITOSA et al., 2019; OLIVEIRA et al., 2020). Thus, it is important to develop training courses that are capable of socializing the correct conditions for handling fish breeded in the Amazon. Given the above, the objective was to train aquaculture farmers in BPM and develop social technologies for aquaculture of tambaqui in Marajó, Pará, Brazil.

\section{MATERIALS AND METHODS}

\section{Study area}

The study was carried out in the municipality of Curralinho, archipelago of Marajó, Pará, Brazil (Figure 1). Marajó is located on the Amazon coast (AMARAL et al., 2012). Region that comprises 16 municipalities, which compose the Arari microregions (Cachoeira do Arari, Chaves, Muaná, Ponta de Pedras, Salvaterra, Santa Cruz do Arari and Soure), Furos de Breves (Afuá, Anajás, Breves, Curralinho and São Sebastião da Boa Vista) and Portel (Bagre, Gurupá, Melgaço and Portel). Curralinho has a territorial extension of 3,620,279 $\mathrm{km} 2$, its population is estimated at 33,893 people in 2018 (IBGE, 2010). The majority of this population is riverside, due to the city being surrounded by rivers and islands, They are aquaculture farmers, fishermen, 
extractivists and family farmers.

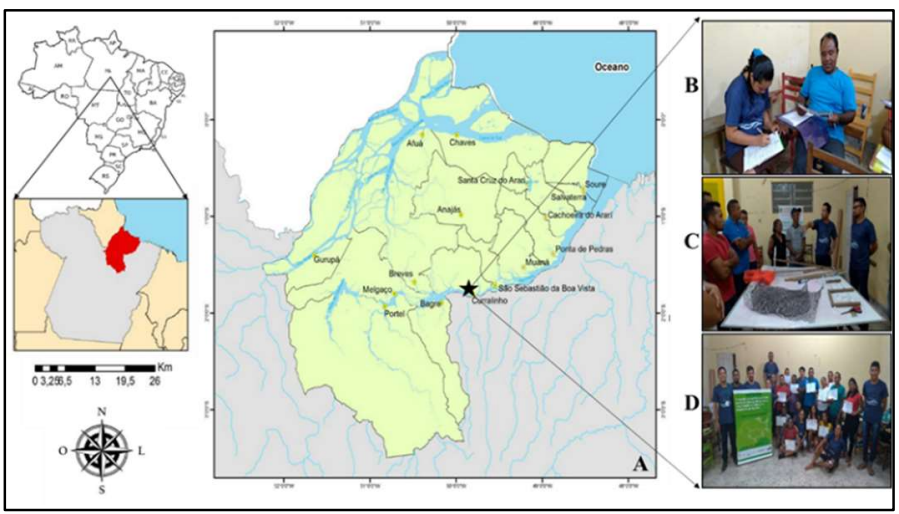

Figure 1: Location of the study area, indicating: a) municipality of Curralinho, Marajó, Pará, Brazil; b), c) and d) students in extension activities. Prepared by Christian Nunes.

\section{The extension Project}

The project 'Transfer of technology through training and technical assistance for tambaqui breeders, Colossoma macropomum in the archipelago of Marajó/PA'. It was funded by the Dean of Extension and External Relations (PROEX) of the Federal Institute of Education, Science and Technology of Pará (IFPA), under call number 03/2019. It was conducted by students regularly enrolled on the Undergraduate Course in Rural Education and the Technical Course in Aquaculture at IFPA Campus Breves. The students received financial support for the acquisition of materials necessary for their execution and scholarships for extension. They participated in all stages of the project, such as: conducting structured interviews and training aquaculture farmers (course participants) in Good Management Practices (BPM) in aquaculture, acting as researchers and instructors, respectively.

\section{Application of questionnaires}

Two semi-structured questionnaires with open and closed questions were used for aquaculture farmers involved in the project (Table 1). On the first day of the course, before the start of activities, a questionnaire was applied, consisting of open and closed questions for 13 enrolled people (initial questionnaire). At this time, basic information about fish farming and BPM adoption was collected. At the end of the project, on the last day of the course, a questionnaire was applied consisting of closed questions to 13 people about the training course (final questionnaire). The use of this tool is a meeting between people, so that one of them obtains information about a certain subject, through a conversation of professional nature (MARCONI; LAKATOS, 2010).

Table 1: Questionnaires applied to course participants in Curralinho, Marajó archipelago, Brazil.

\begin{tabular}{|l|l|}
\hline Before Course & After Course \\
\hline Time working in the activity & Course content and organization \\
\hline Technical assistance assistance & Applicability of the practical part \\
\hline Problems faced in the activity & Development of social technologies \\
\hline Training courses on good practices & Duration of the course \\
\hline Interest in participating in courses in the area & Instructors \\
\hline Expectations and benefits in relation to the course & General course evaluation \\
\hline
\end{tabular}




\section{Training and social Technologies}

The BPM (theory and practice) course was taught by students involved in the extension project, adapted from Verdejo (2006). For this, there were guidelines of students with teachers in the area of Fisheries Engineering and Fishery Resources at IFPA Campus Breves. Initially, a technical meeting was held with the work team for articulation. At that meeting, the extension project was presented and followed a discussion about the BPM course. After that, the target audience was defined and the technical program was planned focusing on bottlenecks of the tambaqui culture, such as: 1) water quality, 2) indicated species, 3) fish transport management, 4) quarantine and stocking of fish, 5) management of fish biometrics, 6) liming and fertilization of tanks, 7) management of fish nutrition and health, and 8) fishing and slaughtering of fish. The course was held in March 2020, lasting 20 hours. Social technologies for the culture of tambaqui were built. For this, teachers, students and course participants participated in the construction workshop. Simple language was used to build the technology, in order to provide a better understanding by fish farmers. For making, alternative and low-cost materials were used, taking into account the reality of local fish farming.

\section{Ethical considerations}

This work is qualitative and was approved by the Research Ethics Committee of the Institute of Health Sciences (CEP) of the Federal University of Pará (UFPA), registration number 2.576.907. The participants' identities were kept confidential, guaranteeing their anonymity and confidentiality of the information.

\section{Statistical analysis}

The collected data were analyzed using descriptive statistics (OLADEJO, 2010).

\section{RESULTS AND DISCUSSION}

\section{Profile of participants and interview}

In the training course, men and women participate (Table 2). We observed the predominance of males (62\%) and the smallest part of females. However, it is in agreement with Amachree et al. (2019), who suggest that women also participate in aquaculture. We emphasize that they are represented in a smaller number, however, the female presence in aquaculture has, over the years, left anonymity and acquired visibility. Since then, the number of studies addressing gender has grown, indicating that gender is fundamental to understanding how men and women participate in the aquaculture production chain (BOSMA et al., 2018; OPARINDE, 2019).

In the present study, $77 \%$ of fish farmers work with fish farming for 1 to 10 years (Table 2). They stressed that the BPM course will strengthen the local production chain. We observed several groups of people looking to start or deepen their knowledge in fish farming. We identified fishermen (60\%), students $(10 \%)$, farmers $(20 \%)$ and domestic workers $(10 \%)$ in the training course. The project reached an audience of eight locations, highlighting the communities: Boa Esperança (8\%), Cafezal (8\%), Ilha das Araras (23\%), 
Perpétuo Socorro (8\%), Piriá Miri (8\%), Rio Açú (15\%), Santa Izabel (15\%) and groups of people from the city of Curralinho (15\%). A determining factor in the participation of some people in the course, according to the students themselves, was the difficulty of locomotion and availability due to their work. This possibly contributed to a low number of people from other rural communities. Short courses are an excellent strategy for rapid training, they appear as alternatives to long courses (ROCHA-VIDIGAL et al., 2012).

Table 2: Information from the first questionnaire, before the training course in BPM in aquaculture in Curralinho, Marajó archipelago, Brazil.

\begin{tabular}{|c|c|c|}
\hline Before course & Absolute frequency (n) & Relative frequency (\%) \\
\hline \multicolumn{3}{|l|}{ Gender } \\
\hline Male & 08 & 62 \\
\hline Female & 05 & 38 \\
\hline \multicolumn{3}{|l|}{ Time working in the activity } \\
\hline 1 to 10 years & 10 & 77 \\
\hline 11 to 20 years & 02 & 15 \\
\hline More than 21 years & 01 & 08 \\
\hline \multicolumn{3}{|c|}{ Receives technical assistance } \\
\hline Yes & 05 & 38 \\
\hline No & 08 & 62 \\
\hline \multicolumn{3}{|c|}{ Problems faced in the activity } \\
\hline Professional qualification & 06 & 46 \\
\hline Technical assistance & 05 & 38 \\
\hline Financial resources & 01 & 08 \\
\hline Production outflow & 01 & 08 \\
\hline \multicolumn{3}{|l|}{ Has training in aquaculture } \\
\hline Yes & 04 & 31 \\
\hline No & 09 & 69 \\
\hline \multicolumn{3}{|c|}{ Interest in training in good practices } \\
\hline Yes & 13 & 100 \\
\hline No & 00 & 00 \\
\hline
\end{tabular}

In Curralinho, aquaculture farmers create tambaqui (Colossoma macropomum). According to the producers, the species was chosen because it is easy to handle, easy to obtain young forms and is well accepted in the local market. However, a total of $62 \%$ of aquaculture farmers claim not to receive technical assistance in aquaculture enterprises, from the competent government agency (Table 2). It is worth considering that the labor used is familiar. Family employment reduces costs during fish production, in addition to contributing to the family's joint work. A total of $46 \%$ of aquaculture farmers claim that professional qualification in aquaculture is not practiced in the region, being a major problem for the disappearance of the activity. The majority of course participants had not yet participated in any training course $(69 \%)$ and those who have already participated represent 31\% (Table 2). We observed that all aquaculture farmers showed interest in the BPM course. Training aims to contribute to the development of skills, and it is necessary to seek new learning possibilities to optimize individual results (MAPA, 2015).

\section{Training and social technologies}

The water quality, the biometrics, the nutrition and the health of fish, were the subjects that attracted the most attention of the course participants (Figure 2). In the view of producers, the variables of water quality (dissolved oxygen, $\mathrm{pH}$, temperature and transparency) are the most important. There are some 
recommendations for dissolved oxygen for tambaqui, on average $\geq 3.0 \mathrm{mg} / \mathrm{L}^{-1}$ (SOUZA et al., 1986). The $\mathrm{pH}$ range close between 5.0 to 8.0 is considered ideal for tropical fish (BOYD, 1982; KUBITZA, 2003). The temperature in fish farming can directly influence food intake (SCORVO et al., 2001). It is worth mentioning that the consumption is reduced or even stopped with the variation of the water temperature beyond its ideal range (SCHMITTOU, 1993). Transparency is a measure directly related to primary production, the water in a nursery when it is transparent, allows you to see the bottom of it, and is a desert of assimilable organic production; consequently, natural foods for fish development are lacking (LEIRA et al., 2017).

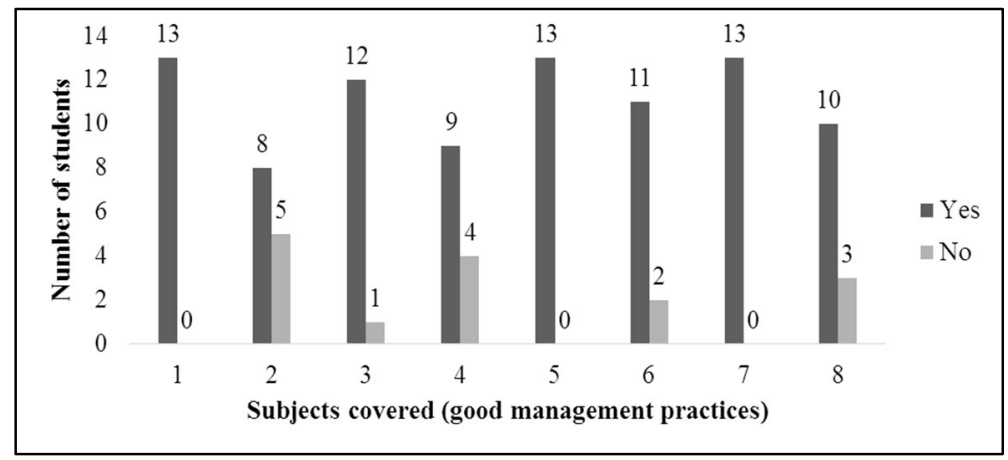

Figure 2: Subjects covered: 1) water quality, 2) indicated species, 3) fish transport, 4) fish quarantine and population, 5) fish biometrics, 6) liming and fertilizing ponds, 7) nutrition and health of fish and 8) fishing and slaughtering of fish, which drew the attention of course participants in Curralinho, Marajó archipelago, Brazil.

With regard to fish biometrics, it is seen that the number of producers that do it is very small, while most do not do it because they don't know what it is about. During biometrics, the entire production process is evaluated in terms of growth and fish health. This management can be adopted, preferably every 15 days or once every 30 days. During this period, the fish will have grown enough to have their food adjusted. Regarding the amount of feed that should be administered to fish, all course participants replied that they do not have a management pattern for the breeding and feeding stages of fish, which puts water quality at risk. It is worth noting that the costs of feeding the fish can correspond to 60 to $80 \%$ of the total production costs (PEREIRA FILHO, 1995).

In our project, producers report that the lack of knowledge in BPM causes the failure of aquaculture. Many were emphatic in saying that they are unaware of the ideal recommendations for fish farming, and the course clarified the importance of adopting this practice in fish farming. We noticed that the course participants acquired basic notions also in the management for the choice of species; fish transport; quarantine and fish stock; liming and fertilizing nurseries; fishing and slaughtering of fish. Training courses are an excellent tool to minimize barriers in the aquaculture production chain. Once socialized, it improves activity and guarantees qualification for the sector (MPA, 2011). Secchi's disk, ichthyometer, fish-trap and tank-net were the social technologies developed during the BPM course (Figure 3).

Diffusion and transfer are inseparable parts of the same process, which includes the generation of technology (FARIAS et al., 2009). This process aims at the adoption of innovations by aquaculture farmers, aiming at sustainable development. The first technology built was a device called the Secchi disk (Figure 3 B), built with a painted cover (white with alternating black bands), approximately 20 to $30 \mathrm{~cm}$ in diameter, with 
4 quadrants, two with a white color and two black, suspended by a broom handle and graduated every centimeter (measuring tape, for example) or with a scale (ruler). The ichthyometer was built with wood, approximately $30 \mathrm{~cm}$ to $50 \mathrm{~cm}$ in length and measuring tape (Figure $3 \mathrm{C}$ ). The fish-trap technologies (Figure $3 \mathrm{D})$ and the net tank (Figure $3 \mathrm{E}$ ), were built with $20 \mathrm{~mm}$ PVC pipe, in addition to the use of bags and polyethylene mesh. Castellani et al. (2005), highlight that fish farming is based on three pillars: profitable production, preservation of the environment and social development, the three components are essential and inseparable, so that one can have an effective activity.

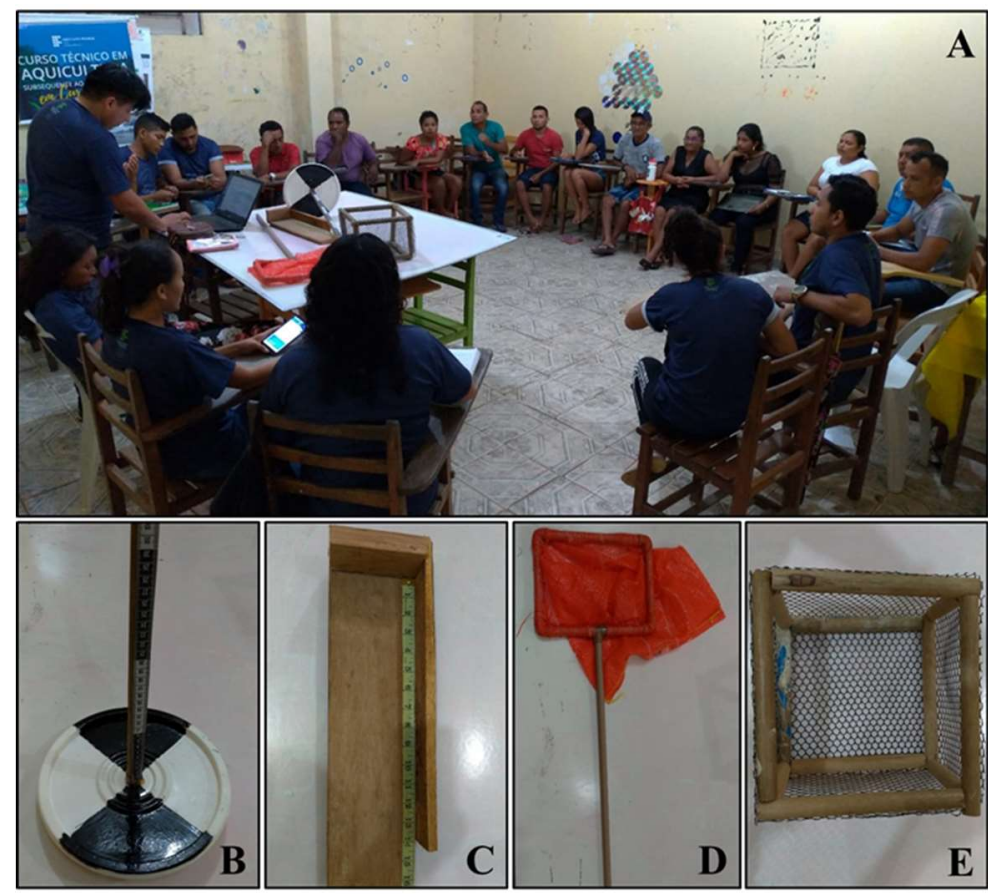

Figure 3: Social technologies: A) Workshop with course participants, B) Secchi disk, C) ichthyometer, D) fish-trap and E) tank-net, developed during the aquaculture training course in Curralinho, Marajó archipelago, Brazil.

\section{Final course evaluation}

With regard to the content covered and the organization of the course, $61 \%$ and $54 \%$ of the participants rated it as excellent, respectively (Table 3 ).

Table 3: Information from the second questionnaire, before the training course on BPM in aquaculture in Curralinho, Marajó archipelago, Brazil.

\begin{tabular}{|l|l|l|}
\hline Post course & Absolute frequency (n) & Relative frequency (\%) \\
\hline Content covered & \multicolumn{2}{|l|}{} \\
\hline Regular & 01 & 08 \\
\hline Good & 04 & 31 \\
\hline Excellent & 08 & 61 \\
\hline Course organization & & \\
\hline Regular & 01 & 08 \\
\hline Good & 05 & 38 \\
\hline Excellent & 07 & 54 \\
\hline Practice part application & & \\
\hline Excellent & 13 & 100 \\
\hline Development of social technologies & \multicolumn{2}{|}{} \\
\hline Good & 04 & 31 \\
\hline Excellent & 09 & 69 \\
\hline Duration of the course & \multicolumn{2}{|}{} \\
\hline
\end{tabular}




\begin{tabular}{|l|l|l|}
\hline Regular & 01 & 08 \\
\hline Good & 07 & 54 \\
\hline Excellent & 05 & 38 \\
\hline Instructors & & \\
\hline Good & 03 & 23 \\
\hline Excellent & 10 & 77 \\
\hline General evaluation & \multicolumn{2}{|l|}{} \\
\hline Good & 02 & 15 \\
\hline Excellent & 11 & 85 \\
\hline
\end{tabular}

All respondents think that the practical part was important in the BPM course. Regarding the development of social technologies, $69 \%$ of the participants rated it excellent. A total of $54 \%$ of them pointed out that the duration of the course was good. Regarding the course instructors, $77 \%$ rated it as excellent. In general, the results obtained through the general evaluation demonstrated that the course of good management practices in aquaculture presented an 'excellent' concept on the part of the evaluators (85\%). When students were asked if they would take another aquaculture training course under the IFPA Campus Breves project, $100 \%$ said yes. They reported the importance of having more courses focused on aquaponics, alternative fish feed and fish processing, to strengthen the local production chain. It is worth considering that they would recommend this course to other people who raise fish or who intend to join the activity. It is worth mentioning that the Piscicultura Marajoara project kept $100 \%$ of the initial public, with a certification at the end of the training. We observed that they were able to solve BPM problems in a tambaqui cultivation system. Thus, training is of fundamental importance for the adoption of technologies that enable the increase of quality fish production and the insertion of producers in the production chain (KATO et al., 2017).

\section{CONCLUSIONS}

The profile of the public that sought training in BPM, were men and women from the communities of Boa Esperança, Cafezal, Ilha das Araras, Perpétuo Socorro, Piriá Miri, Rio Açú, Santa Izabel and groups of people from the city of Curralinho. Prior knowledge of the time working in the activity, technical assistance assistance, problem faced in the activity, training courses, interest in participating in courses in the area, expectations and benefits, were essential for the implementation of the BPM course.

Working on water quality, biometrics, fish nutrition and health, were the subjects that attracted the most attention of the course participants, in addition to the construction of the Secchi disk, ichthyometer, fish-trap and net-tank, which were the technologies socialized during the BPM course. Post-course evaluation in the aspects: content and organization; application of the practical part; development of social technologies; duration of the course; instructors and general assessment; were essential to understand the impact of socialization of knowledge provided to the community.

Thus, the Piscicultura Marajoara project reinforced the teaching, research and extension actions of the IFPA Campus Breves, involving students, teachers and the community in favor of strengthening aquaculture in Marajó, Pará, Brazil.

ACKNOWLEDGMENT: To the Dean of Extension (PROEX) of the Federal Institute of Education, Science and 
Technology of Pará (IFPA), for funding the research (Call No. 03/2019). To the Municipality of Curralinho, for structural support during the training of aquaculture farmers in the municipality. To the students and teachers involved in the IFPA Campus Breves 'Piscicultura Marajoara' project.

\section{REFERENCES}

AIZAWA, N.; MASUDA, M.; ITO, L. S.. Current situation of freshwater aquaculture in the lower Amazon River and the potentiality of development. Tropics, v.23, n.3, p.127-134, 2014. DOI: https://doi.org/10.3759/tropics.23.127

AMARAL, D. D.; MANTELLI, L. R.; ROSSETTI, D. F.. Paleoenvironmental control on modern forest composition of southwestern Marajo Island, Eastern Amazonia. Water and Environment Journal, v.26, p.70-84, 2012. DOI: https://doi.org/10.1111/i.1747-6593.2011.00265.x

BOSMA, R. H.; NGUYEN, T. D.; CALUMPANG, L. M.; CARANDANG, S. A.. Gender action plans in the aquaculture value chain: what's missing?. Reviews in Aquaculture, p.111, 2018. DOI: https://doi.org/10.1111/raq.12293

BOYD, C. E.. Water quality management for pond fish culture, development in aquaculture and fisheries science. Elsevier, New York, v.9, p.730, 1982.

CASTELLANI, D.; BARRELLA, W.. Caracterização da piscicultura na região do Vale do Ribeira/SP. Revista Ciência Agrotecnologia, Lavras, v.29, n.1, p.168-176, 2005. DOI: https://doi.org/10.1590/S1413-70542005000100021

DANTAS, D. P.; FLICKINGER, D. L.; COSTA, G. A.; BATLOUNI, S. R.; MORAES-VALENTI, P.; VALENTI, W. C.. Technical feasibility of integrating Amazon river prawn culture during the first phase of tambaqui grow-out in stagnant ponds, using nutrient-rich water. Aquaculture, n.516, 2019. DOI: https://doi.org/10.1016/j.aquaculture.2019.734611

FAO. El Estado Mundial de la Pesca y la Acuicultura 2006. Roma: organización de las Naciones Unidas para la Agricultura y la Alimentación, 2007. 2006.

FARIAS, J. L. S.; MENDES, M. E. P.. Estratégia de transferência de tecnologia como forma de apropriação do conhecimento: o caso Coomanta Sobral. Embrapa Caprinos e Ovinos, 2009.

FEITOSA, G. P.; SOUSA, K. N. S.. Rede ACQUAPACITA: capacitação universitária para o desenvolvimento do segmento pesqueiro: aquícola de Santarém/PA. Revista de Extensão da Integração Amazônica, Santarém, v.1, n.2, 2019.

FERREIRA, G.; MARCOVITCH, J.; VAL, A.. A systematic review of the production chain of the Arapaima gigas, the giant fish of the Amazon. Management of Environmental Quality: An International Journal, v.31, n.2, 2020. DOI: https://doi.org/10.1108 / MEQ-11-2019-0238

IBGE. Instituto Brasileiro de Geografia e Estatística. Censo demográfico brasileiro 2010. Resultados gerais da amostra. Rio de Janeiro: IBGE, 2012.
KATO, H. C. A.; EVANGELISTA, D. K. R.; SOUSA, D. N.; MATAVELI, M.. Transferência de tecnologia em piscicultura de água doce: a experiência do projeto 'Peixe Mais' no estado do Tocantins. Em Extensão, v.16, n.2, p.129-146, 2017. DOI: https://doi.org/10.14393/REE v16n22017 art06

KLEIN, J. D. L.; COSTA, M.; BUENO, W.; BITTENCOURT, F. R.. Capacitação e Acompanhamento Técnico de Piscicultores Familiares na Região Fronteiriça do Sudoeste do Paraná. Revista Brasileira de Agroecologia, v.4, n.2, 2009.

KUBITZA, F.. Qualidade da água no cultivo de peixes e camarões. Jundiaí: Kubitza, 2003.

LEIRA, M. H.; CUNHA, L. T.; BRAZ, M. S.; MELO, C. C. V.; BOTELHO, H. A.; REGHIM, L. S.. Qualidade da água e seu uso em pisciculturas. PUBVET, v.11, n.1, p.11-17, 2017. DOI: https://doi.org/10.22256/PUBVET.V11N1.11-17

MAPA. Ministério da Agricultura, Pecuária e Abastecimento. Capacitação. MAPA, 2015.

MARCONI, M. A.; LAKATOS, E. M.. Técnicas de pesquisas: Planejamento e execução de pesquisas, amostragens e técnicas de pesquisas, elaboração, análise e interpretação de dados. 3 ed. São Paulo: Atlas, 2010.

MEDEIROS, M.; AUBIN, J.; CAMARGO, A.. Life cycle assessment of fish and prawn production: Comparison of monoculture and polyculture freshwater systems in Brazil. Journal od of Cleaner Production, v.156, p.528-537, 2017. DOI: https://doi.org/10.1016/j.jclepro.2017.04.059

MPA. Ministério da Pesca e Aquicultura. Boletim Estatístico da Pesca e Aquicultura, Brasília. 2011.

OLADEJO, A. J.. Economic analysis of small-scale catfish farming in Ido Local Government Area of Oyo State, Nigeria. Agricultural Journal, v.5, n.6, p.318-321, 2010. DOI: https://doi.org/10.3923/ aj.2010.318.321

OPARINDE, L. O.. Fish Output and Food Security under Risk Management Strategies among Women Aquaculture Farmers in Ondo State, Nigeria. Agris on-line Papers in Economics and Informatics, v.11, n.1, p.93-105, 2019. DOI: https://doi.org/10.22004 / ag.econ.294149

PEREIRA FILHO, M.. Alternativas para a alimentação de peixes em cativeiro. In: VAL, L. A.. Criando peixes na Amazônia. Manaus: Instituto Nacional de Pesquisas da Amazônia, 1995. p.75-82.

ROCHA-VIDIGAL, C. B.; VIDIGAL, V. G.. Investimento na qualificação profissional: uma abordagem econômica sobre sua importância. Acta Scientiarum, Maringá, v.34, n.1, p.41 48, 2012. DOI:

https://doi.org/10.4025/actascihumansoc.v34i1.14181 
SANTOS FILHO, L. G. A.; AGUIAR, S. V.. A contribuição do projeto Mais Piscicultura para a capacitação de pequenos e futuros piscicultores no norte do Piauí. Revista Extensão, v.10, p.123-130, 2016

SCORVO, C. M. F.; CARNEIRO, D. J.; MALHEIROS, E. B.. Efeito do manejo alimentar no desempenho do matrinxã Brycon amazonicus em tanques de cultivo. Acta Amazônica, v.37, n.4, 2007. DOI: https://doi.org/10.1590/S0044$\underline{59672007000400018}$

SCHMITTOU, H.. High density fish culture in low volume cages. Singapore: American Soybean Association, 1993.

SILVA, L. J. S.; PINHEIRO, J. O. C.; CRESCÊNCIO, R.; CARNEIRO, E. F.; PEREIRA, B. P.; BRITO, V. F. S.. Tecnologia e desenvolvimento rural: aspectos do cultivo de tambaqui no município de Rio Preto da Eva, AM. Revista Terceira Margem Amazônia, v.3, n.10, 2018.

SOUZA, E. C. P. M.; TEIXEIRA FILHO, A. R.. Piscicultura fundamental. São Paulo: Nobel, 1986.

VERDEJO, M. E.. Diagnóstico Rural Participativo: Guia Prático DRP. Brasília: MDA, 2006.

ZACARDI, D. M.; LIMA, M. A. S.; NASCIMENTO, M. M.; ZANETTI, C. R. M.. Caracterização socioeconômica e produtiva da aquicultura desenvolvida em Santarém, Pará. Acta of Fisheries and Aquatic Resources, v.5, n.3, p.102-112, 2017.

A CBPC - Companhia Brasileira de Produção Científica (CNPJ: 11.221.422/0001-03) detém os direitos materiais desta publicação. Os direitos referem-se à publicação do trabalho em qualquer parte do mundo, incluindo os direitos às renovações, expansões e disseminações da contribuição, bem como outros direitos subsidiários. Todos os trabalhos publicados eletronicamente poderão posteriormente ser publicados em coletâneas impressas sob coordenação da Sustenere Publishing, da Companhia Brasileira de Produção Científica e seus parceiros autorizados. Os (as) autores (as) posteriormente ser publicados em coletâneas impressas sob coordenação da Sustenere Publishing, da Companhia Brasileira de Produção Científica e seus parce
preservam os direitos autorais, mas não têm permissão para a publicação da contribuição em outro meio, impresso ou digital, em português ou em tradução. 